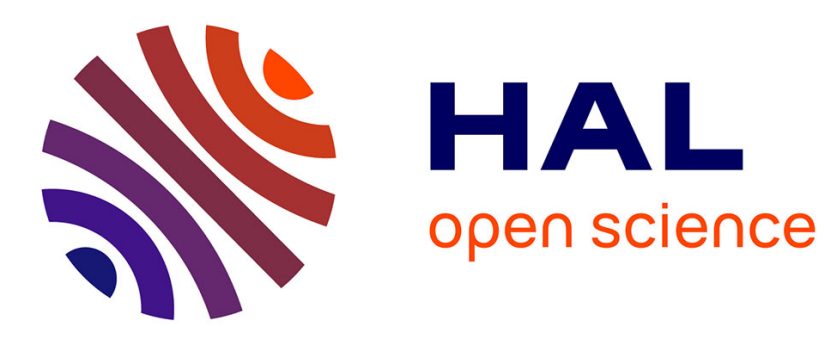

\title{
Ultrasound-directed drug delivery
}

Michiel Postema, Odd Helge Gilja

\section{To cite this version:}

Michiel Postema, Odd Helge Gilja. Ultrasound-directed drug delivery. Current Pharmaceutical Biotechnology, 2007, 8 (6), pp.355-361. 10.2174/138920107783018453 . hal-03193321

\section{HAL Id: hal-03193321 \\ https://hal.science/hal-03193321}

Submitted on 9 Apr 2021

HAL is a multi-disciplinary open access archive for the deposit and dissemination of scientific research documents, whether they are published or not. The documents may come from teaching and research institutions in France or abroad, or from public or private research centers.
L'archive ouverte pluridisciplinaire HAL, est destinée au dépôt et à la diffusion de documents scientifiques de niveau recherche, publiés ou non, émanant des établissements d'enseignement et de recherche français ou étrangers, des laboratoires publics ou privés. 


\section{Ultrasound-directed drug delivery}

Michiel Postema ${ }^{1}$, Odd Helge Gilja ${ }^{2}$

${ }^{1}$ Institute for Medical Engineering, Department of Electrical Engineering and Information Technology, RuhrUniversität Bochum, D-44780 Bochum, Germany and ${ }^{2}$ National Centre for Ultrasound in Gastroenterology, Department of Medicine, Haukeland University Hospital, N-5021 Bergen, Norway

Abstract: It has been proven, that the cellular uptake of drugs and genes is increased, when the region of interest is under ultrasound insonification, and even more when a contrast agent is present. This increased uptake has been attributed to the formation of transient porosities in the cell membrane, which are big enough for the transport of drugs into the cell (sonoporation). Owing to this technique, new ultrasound contrast agents that incorporate a therapeutic compound have become of interest. Combining ultrasound contrast agents with therapeutic substances may lead to a simple and economic method to instantly cure upon diagnosis, using conventional echo machines. There are two hypotheses for explaining the sonoporation phenomenon, the first being microbubble oscillations near a cell membrane, the second being microbubble jetting through the cell membrane. Based on modeling, high-speed photography, and recent cellular uptake measurements, it is concluded that microbubble jetting behavior can be excluded as the dominant sonoporation mechanism.

Keywords: microbubbles, ultrasound, ultrasound contrast agent, drug delivery, sonoporation. 


\section{Ultrasound-directed drug delivery}

\section{INTRODUCTION}

Ultrasonic imaging is a relatively cheap, reliable diagnostic technique. At acoustic pulse lengths and pressures much higher then allowed in diagnostic imaging, ultrasound has therapeutic applications, such as tumor treatment [1, 2] and lithotripsy [3, 4]. But also at clinical diagnostic settings, ultrasound may be used in therapy. It has been proven by numerous groups, that the cellular uptake of drugs and genes is increased, when the region of interest is under ultrasound insonification, and even more when a contrast agent is present [5-30]. This increased uptake has been attributed to the formation of transient porosities in the cell membrane, which are big enough for the transport of drugs into the cell. The transient permeabilization and resealing of a cell membrane is called sonoporation [5]. The underlying mechanisms of sonoporation are discussed in this paper.

Owing to the discovery of sonoporation, new ultrasound contrast agents that incorporate a therapeutic compound have become of interest [12, 26, 27]. A recent overview of studies that have used ultrasound and a contrast agent for the delivery of substances to muscle or vessels is given by [31]. Combining ultrasound contrast agents with therapeutic substances may lead to a simple and economic method to instantly cure upon diagnosis, using conventional echo machines.

\section{MEDICAL ULTRASOUND}

The sound that humans can perceive lies within the frequency range $20 \mathrm{~Hz}-20 \mathrm{kHz}$. Ultrasound is by definition all sound higher than $20 \mathrm{kHz}$. The ultrasound frequencies utilized in medical imaging are mainly in the range 1$30 \mathrm{MHz}$. Ultrasound with such high frequencies is barely transmitted in air but is transmitted satisfactorily in solid or fluid materials. The piezoelectric effect of quartz establishes the foundation for ultrasonic imaging [32]. Langevin theoretically calculated and experimentally verified the fact that a thin sheet of quartz sandwiched between two steel plates constitutes an electromechanical resonant system [32]. An ultrasonic transducer serves a dual function as both transmitter and receiver of ultrasound. A signal generated by an ultrasonic transducer typically consists of a pulse of a few $\mu$ s with a certain center frequency. Part of this signal propagates through target tissue, part is reflected by macroscopic tissue structures, part is absorbed by tissue, and part is scattered by structures in the tissue smaller than the acoustic wavelength. Only a small portion of the transmitted acoustic energy is received by the transducer, which is used to build an ultrasonic image. The received signal is the superposition of specular reflections at tissue boundaries and echoes from tissue backscattering [33]. Current real-time two-dimensional imaging capabilities are in excess of 30 frames per second [34]. An overview of contemporary imaging techniques has been given in [35].

Blood cells are poor scatterers in the clinical diagnostic frequency range. Since imaging blood flow and measuring organ perfusion are desirable for diagnostic purposes, a contrast agent has been added to the blood that helps to differentiate between blood and other tissue types. Ultrasound contrast agents consist of lowsolubility gas microbubbles encapsulated by a stabilizing shell. With mean diameters below $6 \mu \mathrm{m}$, these microbubbles are small enough to pass through the lung capillaries. The composition of the ultrasound contrast agents used most in imaging research are summarized in [33]. The shell usually consists of albumin, lipid, or polymer. The resonance frequencies of ultrasound contrast agent microbubbles lie slightly higher than those of free gas bubbles [36, 37], but well within the clinical diagnostic range.

On clinical ultrasound devices, the intensity of the ultrasonic field is generally adjusted with a switch for the mechanical index instead of the acoustic amplitude. The mechanical index is defined as $\mathrm{MI}=\frac{p^{-}}{\sqrt{f}}$, where $p^{-}$is the maximum value of peak negative pressure anywhere in the ultrasound field, measured in water but reduced by an attenuation factor equal to that which would be produced by a medium having an attenuation coefficient of $0.3 \mathrm{~dB} \mathrm{~cm}^{-1} \mathrm{MHz}^{-1}$, normalized by $1 \mathrm{MPa}$, and $f$ is the center frequency of the ultrasound normalized by $1 \mathrm{MHz}$ [38]. For $\mathrm{MI}<0.3$, the acoustic amplitude is considered low. For $0.3>\mathrm{MI}>0.7$, there is a possibility of minor damage to neonatal lung or intestine [38]. These are considered moderate acoustic amplitudes. For MI $>0.7$, there is a risk of cavitation if an ultrasound contrast agent containing gas microspheres is being used, and there is a theoretical risk of cavitation without the presence of ultrasound contrast agents [38]. The risk increases with MI values above this threshold [38]. These are considered high acoustic amplitudes.

\section{DRUG DELIVERY}


As mentioned in the Introduction section, ultrasound insonification alone increases the cellular uptake, though not as much as with a contrast agent present. In the former case, it has been assumed, that sonoporation is caused by bubbles, which have been generated in the transducer focus as a result of inertial cavitation [39, 40]. Laserinduced cavitation in cells has been shown optically by [41]. In the latter case, the contrast agent can be considered cavitation nuclei.

A microbubble might act as the vehicle to carry a drug or gene load to a perfused region of interest. The load has to be released with the assistance of ultrasound. Apart from mixing ultrasound contrast agent with a therapeutic agent, several schemes have been proposed to combine microbubbles with a therapeutic load:

\section{Therapeutic compounds attached to microbubble shells}

Targeted microbubbles with ligands attached to them may be applied for selective delivery to the areas where selective enhancement of the action of ultrasound would be required. If such a bubble contains plasmid DNA, enzyme, or another therapeutic agent, it might be released at the site of interest during insonification [42].

The albumin shells of contrast microbubbles can bind proteins and oligonucleotides [22]. Local gene delivery of a virus vector attached to albumin-encapsulated microbubbles has been performed in vivo [43]. It was demonstrated in vitro, that higher doses of DNA were delivered during ultrasound insonification when the DNA was loaded on albumin-encapsulated micorbubbles than when unloaded microbubbles were mixed with plasmid DNA [8].

\section{Therapeutic compounds in the gaseous phase}

Sonic cracking is the ultrasound-induced release of gas from thick-shelled microbubbles. Therapeutic compounds in the gas phase might be encapsulated with thick shells, to keep them from dissolving. At the region of interest, the shell can be cracked with ultrasound, releasing the content [44-47].

Few therapeutic compounds exist in the gaseous phase, e.g. nitric oxide [48] and gaseous anaesthetics.

\section{Gas-filled lipospheres containing drugs}

May et al. performed high-speed optical experiments on microbubbles with an outer lipid layer, an oil layer, and a gas core [49]. Such microbubbles may be applicable in local drug delivery, since their lipid-oil complex can carry bioactive substances at high concentrations [50]. The delivery of the contents of these microbubbles has been demonstrated in vitro and ex vivo [50].

Ultrasound-directed delivery of gas-filled lipospheres containing Paclitaxel, a highly hydrophobic chemotherapeutic, has been proposed in [50, 51].

\section{Drug-filled antibubbles}

A therapeutic agent inside the microbubble shell may react with the shell and damp the bubble oscillations. Therefore, it might be more suitable to have the therapeutic agent in the core of the microbubble, separated form the shell by a gaseous layer. Incorporating a liquid drop containing drugs or genes inside an ultrasound contrast agent microbubble, however, is technically challenging [52].

As opposed to bubbles, antibubbles consist of a liquid core surrounded by a gas encapsulation [53]. Such a droplet inside a bubble may be generated with the jetting phenomenon: The collapse of a bubble near a free surface produces a liquid jet [54], which may break up into one or several droplets [55].

In order to develop and improve these drug delivery methods, the underlying mechanisms of microbubbleenhanced uptake have to be understood. Therefore, we explore the physics of medical bubbles subjected to ultrasound.

\section{PHYSICAL PROPERTIES OF MEDICAL BUBBLES}

A bubble in a sound field can be considered a forced damped harmonic oscillator:

$$
m \ddot{x}+\beta \dot{x}+s x=F(t),
$$


where $m$ is the mass of the bubble-liquid system, $x$ the bubble excursion, $\beta$ the mechanical resistance, $\mathrm{s}$ the stiffness of the system, and $F(t)$ the driving force. Because the parameters $m, \beta$, and $s$ are radius-dependent, this ordinary differential equation has to be paraphrased.

The spherically symmetric oscillating behavior of ultrasound contrast agent microbubbles has been described with models based on the Rayleigh-Plesset equation, modified for the presence of a shell [56-60]. Generally, the presence of blood has a relatively small effect on bubble dynamics [61]. Figure 1 demonstrates the oscillation behavior of contrast microbubbles subjected to continuous sine pressure waves with low, moderate, and high amplitudes. Both bubbles oscillate linearly at $\mathrm{MI}=0.01$. With increasing driving amplitude, asymmetries in radial excursion and expansion time rise, especially for the bigger bubble, which is closer to the resonance size. At $\mathrm{MI}=0.8$, both bubbles expand to a factor of the initial size, followed by a rapid collapse for the smaller bubble. The bigger bubble demonstrates collapses at $\mathrm{MI}=0.18$ and higher.

If a bubble with a negligible shell collapses near a free or a solid boundary, the retardation of the liquid near the boundary may cause a bubble asymmetry. This asymmetry causes differences in acceleration on the bubble surface. During further collapse, a funnel-shaped jet may protrude through the bubble, shooting liquid to the boundary [62]. Such jets have been observed in high-speed observations of contrast microbubbles [63-65]. Empirical relations between bubble radius, jet length, and pressure at the tip of jets have been published in [6668]:

$$
\frac{r_{\mathrm{j}}}{r_{\mathrm{c}}} \approx 0.1, \quad \frac{l_{\mathrm{j}}}{r_{\mathrm{c}}} \approx 3,
$$

where $r_{\mathrm{j}}$ is the jet radius, $r_{\mathrm{c}}$ the bubble radius at the verge of collapse, and $l_{\mathrm{j}}$ the jet length. A high-speed photograph of a jet through a contrast microbubble with $r_{\mathrm{c}}=8.4 \mu \mathrm{m}$ and $l_{\mathrm{j}}=26.2 \mu \mathrm{m}$ was published in [69].

During the collapse phase, a bubble may fragment into a number of smaller bubbles [70]. Fragmentation has been observed with contrast agents with thin elastic shells. The number of fragments into which a contrast microbubble breaks up has been associated with asymmetric oscillations [69]. Fragmentation can be predicted from the moment when the kinetic energy of the bubble surpasses its surface energy [71].

Thick-shelled bubbles have demonstrated gas release during a high-amplitude ultrasonic cycle [45, 47]. The increased pressure difference between inside and outside of the bubble during the expansion phase of the wave [48] causes the shell to be stretched across a critical deformation, resulting into its mechanical cracking. The released bubble has an oscillation amplitude much higher than an encapsulated bubble of the same size.

Therefore, the acoustic signal from a contrast agent after gas release differs from that of the same contrast agent before gas release, until the released gas has dissolved [72]. Jetting has been observed with released bubbles, as well [64].

After a disruptive ultrasonic burst, the disappearance of microbubble fragments or released gas may be traced with low-amplitude ultrasound, as well as the wash-in rate of fresh contrast agent [73]. Hence, the effectiveness of the disruptive burst can be measured.

Owing to primary radiation forces, at low-MI, microbubbles can be forced to translate away from the transducer, to, for example, vessel walls $[50,74,75]$, increasing the success rate of targeting to a boundary.

\section{WHAT CAUSES SONOPORATION?}

There are two hypotheses for explaining the sonoporation phenomenon, the first being microbubble oscillations near a cell membrane, the second being microbubble jetting through the cell membrane. It was demonstrated that moderate microbubble oscillations are sufficient to achieve rupture of lipid membranes, in a regimen in which the bubble dynamics can be accurately controlled [76]. However, it was also computed that the pressure at the tip of the jet through a contrast microbubble is high enough to penetrate any human cell [69].

The behavior of contrast agent microbubbles near cells has been recently studied with high-speed photography in [65, 77-83]. Several high-speed image sequences reveal jetting through cells [65], which, however, might be attributed to a solid substratum beneath the cell culture. Even in a controlled experimental environment, contrast jetting is quite rare [69]. Other sequences demonstrate more subtle movements of the cell membrane as a result of microbubble oscillations, combination with an improved cellular uptake [82].

It has been reported that there is an inverse correlation between cell permeability and cell viability [84-86], indicating that sonoporation is just a transitory membrane damage in the surviving cell [86]. Karshafian et al. also found, that contrast microbubbles insonified near a cell at any acoustic pressure used cause large pores 
(300-500 nm), whereas microbubbles insonified at high acoustic pressures cause smaller pores (20-500 nm), too, in more cells [86]. Pores on the order of 10-100 nm were observed with two different methods by [87], with pores opening lasting only milliseconds to seconds.

The two contrast agents used in [86] have mean diameters 1.1-3.3 and 2.0-4.5 $\mu \mathrm{m}$, respectively [33]. The lower and upper limit of these diameters has been modeled and shown in Figure 1. A conservative model [33] had been chosen, and a conservative estimate of the shell stiffness [88] had been used. Still, using the empirical jetting relations in (2), the maximal expansions computed would be high enough to create pores of more than $1 \mu \mathrm{m}$. In order to create pores of $20 \mathrm{~nm}$ by jetting, the contrast microbubble diameter at the verge of collapse should be approximately $0.2 \mu \mathrm{m}$. For the agents chosen, this is a highly unrealistic value.

These findings indicate that microbubble jetting behavior does not play an important role in sonoporation. The influence of microbubble disruption, i.e., fragmentation or sonic cracking, on sonoporation will have to be further investigated.

\section{LIST OF FIGURES}

Figure 1: Radius-time curves (normalized by equilibrium radius) of contrast microbubbles with a $1.1 \mu \mathrm{m}$ (left column) and a $4.5 \mu \mathrm{m}$ (right column) equilibrium diameters, respectively, modeled with a conservative

Rayleigh-Plesset equation [33], using a conservative shell friction parameter of $\frac{4}{8 \pi} \mathrm{kg} \mathrm{s}^{-2}$ [88]. The modeled ultrasound field was a continous sine wave with a frequency of $0.5 \mathrm{MHz}$ and acoustic amplitudes corresponding to (top-down) $\mathrm{MI}=0.01,0.1,0.18,0.35$, and 0.8 , similar to the experiments presented in [86].

Figure 2: Ultrasound-induced formation of an antibubble (A) and a schematic representation thereof (B). Each frame corresponds to a $71 \times 52 \mu \mathrm{m}^{2}$ area. Frame 0 was captured before ultrasound arrival. Frames 1-10 cover 5 $\mu \mathrm{s}$, captured during insonification. This corresponds to four frames per ultrasonic cycle. The depth-of-field is approximately $5 \mu \mathrm{m}$, causing a stacked representation of three-dimensional microobjects. In frame 0 , a big free gas microbubble with a $30 \mu \mathrm{m}$ diameter is seen just below a $7.5 \mu \mathrm{m}$ Quantison ${ }^{\mathrm{TM}}$ microbubble that is slightly out of optical focus. After ultrasound arrival, presumably gas release takes place from the Quantison ${ }^{\mathrm{TM}}$ microbubble. This new microbubble is seen to expand and contract in the following frames. The two microbubbles interact, leading to an instability at the surface of the big free gas microbubble (frame 2). This instability has the form of a re-entrant jet protruding into the gas microbubble. The inward protrusion grows until frame 4 . Between frames 5 and 8 , the cylindrical protrusion drains. In frame 9, a $5 \mu \mathrm{m}$ droplet is left inside the gas microbubble, while the protrusion retracts. Frame 10 shows the resulting antibubble: a spherical liquid core inside a spherical gas encapsulation. ( 2005 IEEE. Reprinted with permission from Postema, M., de Jong, N., Schmitz, G., van Wamel, A. (2005) Proc. IEEE Ultrason. Symp., 977-980.

\section{REFERENCES}

[1] ter Haar, G. R. (2001) Echocardiography 18 (4), 317-322.

[2] Liu, Y., Kon, T., Li, C., and Zhong, P. (2005) J. Acoust. Soc. Am. 118 (5), 3328-3336.

[3] Eisenmenger, W. (2001) Ultrasound Med. Biol. 27 (5), 683-693.

[4] Eisenmenger, W., Du, X. X., Tang, C., Zhao, S., Wang, Y., Rong, F., Dai, D., Guan, M., and Qi, A. (2002) Ultrasound Med. Biol. 28 (6), 769-774.

[5] Bao, S., Thrall, B. D., and Miller, D. L. (1997) Ultrasound Med. Biol. 23 (6), 953-959.

[6] Chen, S., Shohet, R. V., Bekeredjian, R., Frenkel, P., and Grayburn, P. A. (2003) J. Am. Coll. Cardiol. 42 (2), 301-308.

[7] Delius, M., Hofschneider, P.-H., Lauer, U., and Messner, K. (1995) Lancet 345, 1377.

[8] Frenkel, P. A., Chen, S., Thai, T., Shohet, R. V., and Grayburn, P. A. (2002) Ultrasound Med. Biol. 28 (6), 817-822.

[9] Greenleaf, W. J., Bolander, M. E., Sarkar, G., Goldring, M. B., and Greenleaf, J. F. (1998) Ultrasound Med. Biol. 24 (4), 587-595.

[10] Kondo, I., Ohmori, K., Oshita, A., Takeuchi, H., Fuke, S., Shinomiya, K., Noma, T., Namba, T., and Kohno, M. (2004) J. Am. Coll. Cardiol. 44 (3), 644-653.

[11] Lawrie, A., Brisken, A. F., Francis, S. E., Wyllie, D., Kiss-Toth, E., Qwarnstrom, E. E., Dower, S. K., Crossman, D. C., and Newman, C. M. (2003) Ultrasound Med. Biol. 29 (10), 1453-1461.

[12] Lindner, J. R., and Kaul, S. (2001) Echocardiography 18 (4), 329-337. 
[13] Manome, Y., Nakayama, N., Nakayama, K., and Furuhata, H. (2005) Ultrasound Med. Biol. 31 (5), 693-702.

[14] Miller, D. L., Bao, S., Gies, R. A., and Thrall, B. D. (1999) Ultrasound Med. Biol. 25 (9), 1425-1430.

[15] Miller, D. L., Bao, S., and Morris, J. E. (1999) Ultrasound Med. Biol. 25 (1), 143-149.

[16] Miller, D. L., and Dou, C. (2004) Ultrasound Med. Biol. 30 (3), 405-411.

[17] Miller, D. L., and Dou, C. (2004) Ultrasound Med. Biol. 30 (7), 973-977.

[18] Mukherjee, D., Wong, J., Griffin, B., Ellis, S. G., Porter, T., Sen, S., and Thomas, J. D. (2000) J. Am. Coll. Cardiol. 35 (6), 1678-1686.

[19] Newman, C. M., Lawrie, A., Brisken, A. F., and Cumberland, D. C. (2001) Echocardiography 18 (4), 339-347.

[20] Pislaru, S. V., Pislaru, C., Kinnick, R. R., Singh, R., Gulati, R., Greenleaf, J. F., and Simari, R. D. (2003) Eur. Heart J. 24, 1690-1698.

[21] Porter, T. R., and Xie, F. (2001): Targeted drug delivery using intravenous microbubbles, pp. 347-351. In B. B. Goldberg, J. S. Raichlen, and F. Forsberg (Eds): Ultrasound Contrast Agents. Basic principles and clinical applications, Martin Dunitz Ltd, London.

[22] Porter, T. R., and Xie, F. (2001) Echocardiography 18 (4), 349-353.

[23] Song, J., Chappell, J. C., Qi, M., VanGieson, E. J., Kaul, S., and Price, R. J. (2002) J. Am. Coll. Cardiol. 39 (4), 726-731.

[24] Tachibana, K., and Tachibana, S. (2001) Echocardiography 18 (4), 323-328.

[25] Tachibana, K., Uchida, T., Ogawa, K., Yamashita, N., and Tamura, K. (1999) Lancet 353, 1409.

[26] Unger, E. C., Hersh, E., Vannan, M., and McCreery, T. (2001) Echocardiography 18 (4), 355-361.

[27] Unger, E. C., Matsunaga, T. O., McCreery, T., Schumann, P., Sweitzer, R., and Quigley, R. (2002) Eur. J. Radiol. 42, 160-168.

[28] Taniyama, Y., Tachibana, K., Hiraoka, K., Namba, T., Yamasaki, K., Hashiya, N., Aoki, M., Ogihara, T., Yasufumi, K., and Morishita, R. (2002) Circulation 105, 1233-1239.

[29] van Wamel, A., Bouakaz, A., Bernard, B., ten Cate, F., and de Jong, N. (2004) Ultrasonics 42 (1--9), 903-906.

[30] Mehier-Humbert, S., Bettinger, T., Yan, F., and Guy, R. H. (2005) J. Control. Release 104, $203-211$.

[31] Bekeredjian, R., Grayburn, P. A., and Shohet, R. V. (2005) J. Am. Coll. Cardiol. 45 (3), 329-335.

[32] Klein, E. (1948) J. Acoust. Soc. Am. 20 (5), 601-604.

[33] Postema, M., and Schmitz, G. (2006) Expert Rev. Mol. Diagn. 6 (3), in press.

[34] Webb, A. (2003) Introduction to Biomedical Imaging. John Wiley \\& Sons. Hoboken.

[35] Wells, P. N. T. (1999) Rep. Prog. Phys. 62, 671-722.

[36] MacDonald, C. A., Sboros, V., Gomatam, J., Pye, S. D., Moran, C. M., and McDicken, W. N. (2004) Ultrasonics 43, 113-122.

[37] Guan, J., and Matula, T. J. (2004) J. Acoust. Soc. Am. 116 (5), 2832-2842.

[38] British Medical Ultrasound Society (2000): Guidelines for the safe use of diagnostic ultrasound equipment.

[39] Miller, D. L., and Nyborg, W. L. (1983) J. Acoust. Soc. Am. 73 (5), 1537-1544.

[40] Miller, D. L., and Song, J. (2002) Ultrasound Med. Biol. 28 (10), 1343-1348.

[41] Zohdy, M. J., Tse, C., Ye, J. Y., and O'Donnell, M. (2006) IEEE Trans. Ultrason., Ferroelect., Freq. Contr. 53 (1), 117-125.

[42] Klibanov, A. L. (1999) Adv. Drug Delivery Rev. 37, 139-157.

[43] Shohet, R. V., Chen, S., Zhou, Y.-T., Wang, Z., Meidell, R. S., Unger, R. H., and Grayburn, P. A. (2000) Circulation 101, 2554-2556.

[44] Dayton, P., Morgan, K., Allietta, M., Klibanov, A., Brandenburger, G., and Ferrara, K. (1997) Proc. IEEE Ultrason. Symp., 1583-1591.

[45] Postema, M., Bouakaz, A., Versluis, M., and de Jong, N. (2005) IEEE Trans. Ultrason., Ferroelect., Freq. Contr. 52 (6), 1035-1041.

[46] Takeuchi, Y. (1999) IEEE Trans. Ultrason., Ferroelect., Freq. Contr. 46 (4), ii.

[47] Bloch, S. H., Wan, M., Dayton, P. A., and Ferrara, K. W. (2004) Appl. Phys. Lett. 84 (4), 631-633.

[48] Postema, M., Bouakaz, A., ten Cate, F., Schmitz, G., de Jong, N., and van Wamel, A. (2006) Ultrasonics, in press.

[49] May, D., Allen, J., and Ferrara, K. (2002) IEEE Trans. Ultrason., Ferroelect., Freq. Contr. 49 (10), 1400-1410.

[50] Shortencarier, M. J., Dayton, P. A., Bloch, S. H., Schumann, P. A., Matsunaga, T. O., and Ferrara, K. W. (2004) IEEE Trans. Ultrason., Ferroelect., Freq. Contr. 51 (7), 822-831.

[51] Unger, E. C., McGreery, T. P., Sweitzer, R. H., Caldwell, V. E., and Wu, Y. (1998) Invest. Radiol. 33 (12), 886-892.

[52] Postema, M., de Jong, N., Schmitz, G., and van Wamel, A. (2005) Proc. IEEE Ultrason. Symp., 977980.

[53] Dorbolo, S., Caps, H., and Vandewalle, N. (2003) New J. Phys. 5, 161.1-161.9. 
[54] Katz, J. I. (1999) Proc. R. Soc. London A 455, 323-328.

[55] Duchemin, L., Popinet, S., Josserand, C., and Zaleski, S. (2002) Phys. Fluids 14 (9), 3000-3008.

[56] de Jong, N., Cornet, R., and Lanc $\{\backslash$ 'e\}e, C. T. (1994) Ultrasonics 32 (6), 447-453.

[57] Morgan, K. E., Allen, J. S., Dayton, P. A., Chomas, J. E., Klibanov, A. L., and Ferrara, K. W. (2000)

IEEE Trans. Ultrason., Ferroelect., Freq. Contr. 47 (6), 1494-1509.

[58] Hoff, L., Sontum, P. C., and Hovem, J. M. (2000) J. Acoust. Soc. Am. 107 (4), 2272-2280.

[59] Allen, J. S., May, D. J., and Ferrara, K. W. (2002) Ultrasound Med. Biol. 28 (6), 805-816.

[60] Stride, E., and Saffari, N. (2003) Ultrasound Med. Biol. 29 (4), 563-573.

[61] Stride, E., and Saffari, N. (2004) Ultrasound Med. Biol. 30 (11), 1495-1509.

[62] Philipp, A., and Lauterborn, W. (1998) J. Fluid Mech. 361, 75-116.

[63] Postema, M., Bouakaz, A., and de Jong, N. (2002) IEEE Trans. Ultrason., Ferroelect., Freq. Contr. 49(3), ii.

[64] Postema, M., van Wamel, A., ten Cate, F. J., and de Jong, N. (2005) Med. Phys. 32 (12), 3707-3711.

[65] Prentice, P., Cuschieri, A., Dholakia, K., Prausnitz, M., and Campbell, P. (2005) Nature Phys. 1, $107-$ 110.

[66] Kodama, T., and Takayama, K. (1998) Ultrasound Med. Biol. 24 (5), 723-738.

[67] Ohl, C. D., and Ikink, R. (2003) Phys. Rev. Lett. 90, 214502.

[68] Ohl, C.-D., and Ory, E. (2000): Aspherical bubble collapse --- comparison with simulations, pp. 393396. In W. Lauterborn, and T. Kurz (Eds): Nonlinear Acoustics at the Turn of the Millennium, American Institute of Physics, New York.

[69] Postema, M., van Wamel, A., Lancl'\{e\}e, C. T., and de Jong, N. (2004) Ultrasound Med. Biol. 30 (6), 827-840.

[70] Chomas, J. E., Dayton, P., May, D., and Ferrara, K. (2001) J. Biomed. Opt. 6 (2), 141-150.

[71] Postema, M., and Schmitz, G. (2005) Proc. IEEE Eng. Med. Biol. Soc., 33.01-33.04.

[72] Bevan, P. D., Karshafian, R., Matsumura, M., Tickner, G., and Burns, P. N. (2004) Proc. IEEE Ultrason. Symp., 1391-1394.

[73] Moran, C. M., Anderson, T., Pye, S. D., Sboros, V., and McDicken, W. N. (2000) Ultrasound Med. Biol. 26 (4), 629-639.

[74] Zhao, S., Borden, M., Bloch, S. H., Kruse, D., Ferrara, K. W., and Dayton, P. A. (2004) Mol. Imaging 3 (3), 135-148.

[75] Tortoli, P., Boni, E., Corsi, M., Arditi, M., and Frinking, P. (2005) IEEE Trans. Ultrason., Ferroelect., Freq. Contr. 52 (7), 1183-1188.

[76] Marmottant, P., and Hilgenfeldt, S. (2003) Nature 423, 153-156.

[77] Kudo, N., Kuribayashi, K., Natori, M., Moriyasu, F., and Yamamoto, K. (2001) IEICE Trans. A J84-A (12), 1492-1499.

[78] Kudo, N., Miyaoka, T., Kuribayashi, K., and Yamamoto, K. (2000) J. Acoust. Soc. Am. 108 (5, Pt. 2), 2547.

[79] Kudo, N., Miyaoka, T., Okada, K., Yamamoto, K., and Niwa, K. (2002) Proc. IEEE Ultrason. Symp., 1351-1354.

[80] Wolfrum, B., Mettin, R., Kurz, T., and Lauterborn, W. (2002) Appl. Phys. Lett. 81 (26), 5060-5062.

[81] van Wamel, A., Bouakaz, A., Bernard, B., ten Cate, F., and de Jong, N. (2005) J. Control. Release 101, 389-391.

[82] van Wamel, A., Kooiman, K., Harteveld, M., Emmer, M., ten Cate, F. J., Versluis, M., and de Jong, N. (2006) J. Control. Release, in press.

[83] Okada, K., Kudo, N., Niwa, K., and Yamamoto, K. (2005) J. Med. Ultrasonics 32, 3-11.

[84] Miller, D. L., Dou, C., and Song, J. (2003) Ultrasound Med. Biol. 29 (4), 601-607.

[85] van Wamel, A., Bouakaz, A., ten Cate, F., and de Jong, N. (2002) Proc. IEEE Ultrason. Symp., 13871390.

[86] Karshafian, R., Samac, S., Banerjee, M., Bevan, P. D., and Burns, P. N. (2005) Proc. IEEE Ultrason. Symp., 13-16.

[87] Mehier-Humbert, S., Bettinger, T., Yan, F., and Guy, R. H. (2005) J. Control. Release 104, $213-222$.

[88] Krishna, P. D., Shankar, P. M., and Newhouse, V. L. (1999) Phys. Med. Biol. 44, 681-694. 

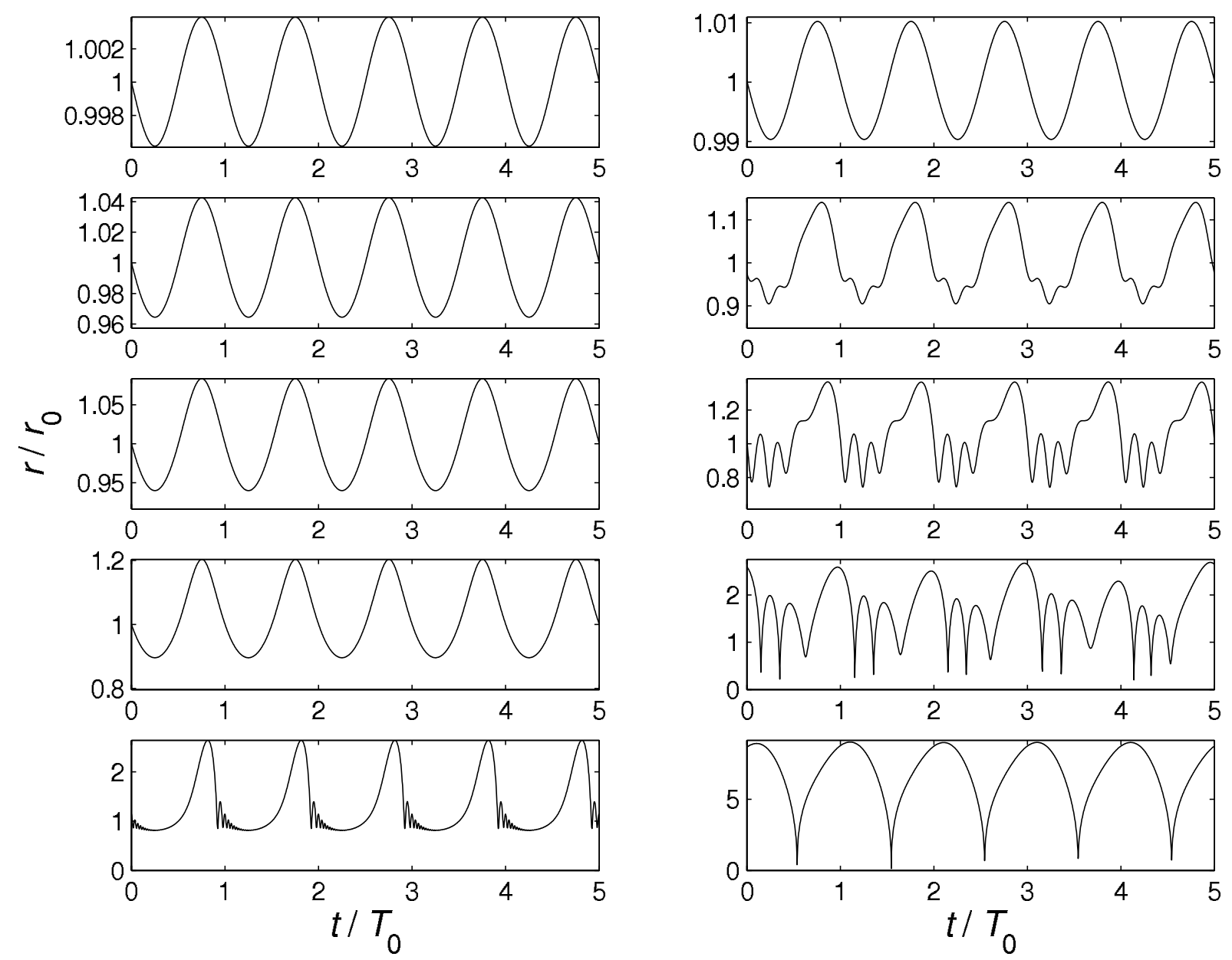

Figure 1
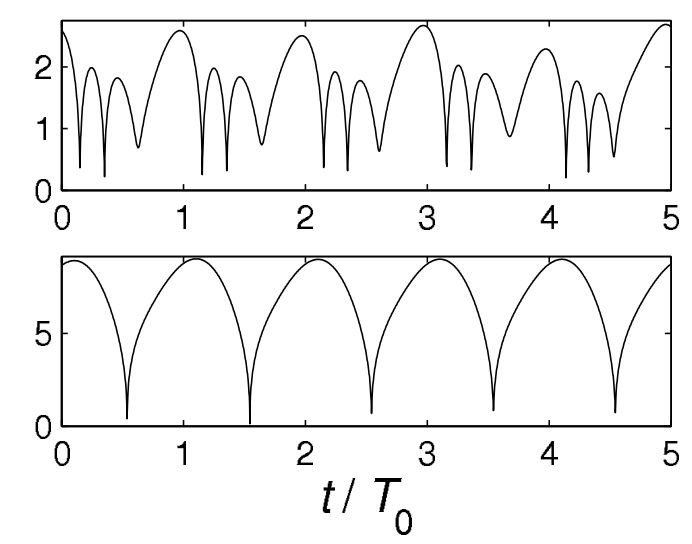

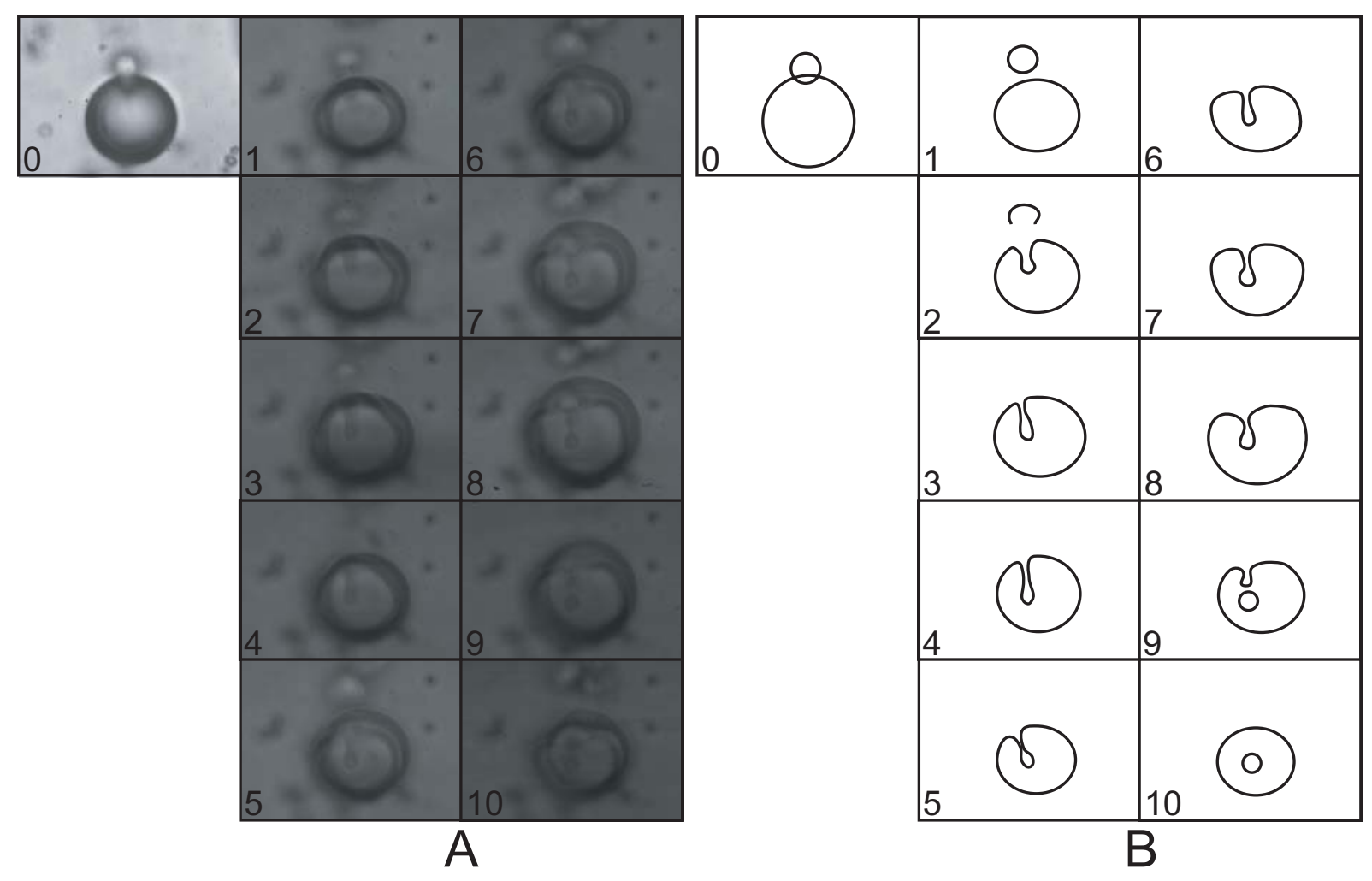

Figure 2 